\title{
Effectiveness of Music Therapy on Social Skill Growth in Educable Intellectual Disability Boys
}

\author{
Peyman Hashemian ${ }^{*}$, Mansoureh Mohammadi² \\ ${ }^{1}$ Psychiatry and Behavioral Sciences Research Center, Ibn-e-Sina Hospital, Faculty of Medicine, Mashhad \\ University of Medical Sciences, Mashhad, Iran \\ ${ }^{2}$ Islamic Azad University, Ghochan, Iran \\ Email: "hashemianp@mums.ac.ir
}

Received 19 November 2015; accepted 27 December 2015; published 30 December 2015

Copyright $@ 2015$ by authors and Scientific Research Publishing Inc.

This work is licensed under the Creative Commons Attribution International License (CC BY). http://creativecommons.org/licenses/by/4.0/

\section{(c) (i) Open Access}

\begin{abstract}
Introduction: Social skills include the ability to establish interpersonal relationships with others in a way that is acceptable in terms of norms of society and it should be beneficial to society and have mutual interest. Method: Sample was taken from especial elementary school for educable intellectual disability children in Mashhad, Iran. The sample was boys between 9 - 11 years. After the initial selection of students, they were randomly assigned to two groups of twenty (experimental and control groups). 7 sessions of music therapy were performed for each one in the experimental group whereas no sessions were applied for anyone in the control group. Winelend Social Growth Scale was used to measure their social skill before and after intervention. Result: The mean difference in social skill between the two groups were statistically less than the 0.01 which is highly significant $(P$-value $=\mathbf{0 . 0 0 0 5})$. This shows that art and music therapy are effective on the growth of social skills in educable intellectual disability children. Conclusion: This research shows that music therapy is effective for improvement of social skills in educable intellectual disability children.
\end{abstract}

\section{Keywords}

Social Skills, Music Therapy, Educable Intellectual Disability Children

\section{Introduction}

Intellectual disability children do not have enough social skill in finding friends, maintaining the friendship and

${ }^{*}$ Corresponding author. 
proper relationship with others, managing any teamwork.

Social skill is to have good relationship with others and find friends and maintain the friendship and cooperate with each other and to be active in social activities. This characteristic is low in intellectual disability children.

Social skill is an important factor in avoidance of negative reaction [1] [2].

One of the important factors in formation of social skill is family function. Kumar et al. [3] in 2009 found that social growth in children with intellectual disability depends on the severity of intellectual disability. Dunn and colleagues [4] in 2004 found the positive effect of social problem solving in individuals with intellectual disability. Heward [5] in 2005 showed that children with intellectual disability need special support and remediation for social growth.

As music therapy provide a field for social activity, they are used in this study to evaluate whether social skill will improve in these intellectual disability students.

Mental disability children are usually unable to socially interact with friends and classmates; and their adjustment in social life is difficult.

Some studies revealed that music has positive impact on human behaviors and mood [6]-[8]. Therefore music has been used for treatment of medical and psychiatric disorders [8] [9]. Some of the most common psychiatric disorders that are treated with music therapy are pain, grief, anxiety, and relationship issues [10]-[12]. Music therapy can regulate the mood and decrease pain by releasing endorphins [13] [14]. Music can also improve function of brain in coping with stress and increases self-satisfaction and self-confidence [15].

Music brings a safe environment for proper social relationship and positive self-esteem and decreases social withdrawal, lack of interest, and aggression [16]-[20].

\section{Method}

This research has been conducted as case-control trial in children with intellectual disability in especial elementary school in Mashhad, Iran in 2013. All children were boys between 9 to 11 years of age who were diagnosed as having mild intellectual disability. 40 children in two groups of 20 were selected randomly. Children in experimental group had taken 7 sessions of music and art therapy whereas control group did not take any sessions of any kind. Both groups were compared by Winelend Social Growth Scale. SPSS software version 20 was used for statistical analysis. Data were analyzed by descriptive test, Leven's test, t-test and one-way ANCOVA for comparison of social growth with art and music therapy.

\section{Results}

The statistical analysis shows the average age in experimental group was 9.9 versus 9.8 in control group. In experimental group, mean score of pre-test was 74.73 and 79.79 in post-test whereas in control group pre-test score was 76.76 and post-test score was 79.36 .

Distribution of social growth in the two groups was normal $(\mathrm{Z}=0.63$, P-value $=0.82)$.

Leven's test was used to evaluate homogeneity of social growth scale in educable mental retarded children (Leven's index $=90$, P-value $=0.35$ ).

Independent $\mathrm{t}$-test shows no significant difference in pre-test score of the two groups $(\mathrm{t}=0.23, \mathrm{P}$-value $=$ $0.32)$.

Table 1 shows highly significant difference in social growth between the two groups in post-test $(\mathrm{P}-\mathrm{value}=$ $0.0005)$.

\section{Discussion}

As known, intellectual disability is characterized by developmental delay in many area of growth such as social, individual, academic achievement and so on. One of the most important difficulties in intellectual disability children is low ability of social interaction that maybe due to poor interaction.

Table 1. The result of ANCOVA between experimental and control groups in social growth.

\begin{tabular}{cccc}
\hline Source & F & 2 Partial $\eta$ & P-value \\
Group & 152.31 & 0.83 & 0.0005 \\
\hline
\end{tabular}


This study compares social skill changes in the two groups of educable intellectual disability male students where only one group goes through music therapy sessions. This study was performed only on male subjects.

The result of this study shows normal distribution of social growth in the two groups. Age and social skill scores in pre-test of the two groups were not significantly different. The result after intervention in the experimental group shows that music therapy made a highly significant change in their social skills. So it is compatible with the results achieved in previous studies on the effect of music therapy in improving psychological function and resolve of some psychiatric disorders including anxiety and improve stress management [7] [10] [11] [16]-[20]. The effect music therapy on social growth may be due to mood regulation [6]-[8] or by improving function of brain in coping with stress, self-satisfaction and self-confidence increases [13]-[15]. As music induces safe environment for good social relationship, it may cause positive self-esteem and increases social approach and interests [16]-[19]. Music therapy may decreases aggression as Habibipour et al., Smeijsters et al and Hashemian et al. showed that music can be effective for control of aggression [16] [17] [20].

\section{Limitation and Suggestion}

This study shows that music therapy was effective in social skill improvement. This may be a trigger for initiation of social relationship and it is probably due to mood improvement. Further researches are suggested to evaluate the effect of art and music therapy on mood state.

Similar research is recommended on female individuals.

\section{Conclusion}

This study shows that music therapy can increase social skill in children with intellectual disability. This fact can be used to solve their social problems. So art and music therapy is recommended as one of the treatments for social skill improvement in these children.

\section{References}

[1] Cartledge, G. and Milburn, J.A.F. (1996) Cultural Diversity and Social Skills Instruction: Understanding Ethnic and Gender Differences. 1st Edition, Research Press, Champaign.

[2] Cartledge, G. and Kourea, L. (2008) Culturally Responsive Classrooms for Culturally Diverse Students with and at Risk for Disabilities. Journal of Exceptional Children, 74, 351-371.

[3] Kumar, I., Singh, A.R. and Akhtar, S. (2009) Social Development of Children with Mental Retardation. Industrial Psychiatry Journal, 18, 56-59. http://dx.doi.org/10.4103/0972-6748.57862

[4] Dunn, C. and Crites, S.A. (2004) Teaching Social Problem Solving to Individuals with Mental Retardation. Education and Training in Developmental Disabilities, 39, 301-309.

[5] Heward, W.L. (2003) Ten Faulty Notions about Teaching and Learning That Hinder the Effectiveness of Special Education. The Journal of Special Education, 36, 186-205. http://dx.doi.org/10.1177/002246690303600401

[6] Robb, S.L., Burns, D.S., Stegenga, K.A., Haut, P.R., Monahan, P.O., Meza, J., et al. (2014) Randomized Clinical Trial of Therapeutic Music Video Intervention for Resilience Outcomes in Adolescents/Young Adults Undergoing Hematopoietic Stem Cell Transplant: A Report from the Children’s Oncology Group. Cancer, 120, 909-917. http://dx.doi.org/10.1002/cncr.28355

[7] Fritz, T.H., Halfpaap, J., Grahl, S., Kirkland, A. and Villringer, A. (2013) Musical Feedback during Exercise Machine Workout Enhances Mood. Frontiers in Psychology, 4, 921. http://dx.doi.org/10.3389/fpsyg.2013.00921

[8] Ghetti, C.M. (2013) Effect of Music Therapy with Emotional-Approach Coping on Preprocedural Anxiety in Cardiac Catheterization: A Randomized Controlled Trial. Journal of Music Therapy, 50, 93-122. http://dx.doi.org/10.1093/jmt/50.2.93

[9] Fritz, T.H., Hardikar, S., Demoucron, M., Niessen, M., Demey, M., Giot, O., et al. (2013) Musical Agency Reduces Perceived Exertion during Strenuous Physical Performance. Proceedings of the National Academy of Sciences of the United States of America, 110, 17784-17789. http://dx.doi.org/10.1073/pnas.1217252110

[10] Sili, A., Fida, R., Proietti, D., Vellone, E. and Alvaro, R. (2013) Decreasing Preoperative Anxiety by Music: Experimental Study in a Vascular Surgery Unit. Assistenza Infermieristica e Ricerca: AIR, 32, 13-19.

[11] Nightingale, C.L., Rodriguez, C. and Carnaby, G. (2013) The Impact of Music Interventions on Anxiety for Adult Cancer Patients: A Meta-Analysis and Systematic Review. Integrative Cancer Therapies, 12, 393-403. http://dx.doi.org/10.1177/1534735413485817 
[12] Blain-Moraes, S., Chesser, S., Kingsnorth, S., McKeever, P. and Biddiss, E. (2013) Biomusic: A Novel Technology for Revealing the Personhood of People with Profound Multiple Disabilities. Augmentative and Alternative Communication, 29, 159-173. http://dx.doi.org/10.3109/07434618.2012.760648

[13] Vollert, J.O., Stork, T., Rose, M. and Mockel, M. (2003) Music as Adjuvant Therapy for Coronary Heart Disease. Therapeutic Music Lowers Anxiety, Stress and Beta-Endorphin Concentrations in Patients from a Coronary Sport Group. Deutsche Medizinische Wochenschrift, 128, 2712-2716.

[14] Boso, M., Politi, P., Barale, F. and Enzo, E. (2006) Neurophysiology and Neurobiology of the Musical Experience. Functional Neurology, 21, 187-191.

[15] McKinney, C.H., Tims, F.C., Kumar, A.M. and Kumar, M. (1997) The Effect of Selected Classical Music and Spontaneous Imagery on Plasma Beta-Endorphin. Journal of Behavioral Medicine, 20, 85-99. http://dx.doi.org/10.1023/A:1025543330939

[16] Habibipour, M., Habibipour, H., Habibipour, M. and Rejaee, A. (2008) Effect of Iranian Nonverbal Soft Music on the Reduction of Aggression among Boy Students of Mashhad Guidance School. Quarterly Educational Psychology, 3, 45-55.

[17] Smeijsters, H. and Cleven, G. (2006) The Treatment of Aggression Using Arts Therapies in Forensic Psychiatry: Results of a Qualitative Inquiry. The Arts in Psychotherapy, 33, 37-58. http://dx.doi.org/10.1016/j.aip.2005.07.001

[18] Saarikallio, S. and Erkkilä, J. (2007) The Role of Music in Adolescents’ Mood Regulation. Psychology of Music, 35, 88-109. http://dx.doi.org/10.1177/0305735607068889

[19] Labbe, E., Schmidt, N., Babin, J. and Pharr, M. (2007) Coping with Stress: The Effectiveness of Different Types of Music. Applied Psychophysiology and Biofeedback, 3, 163-168. http://dx.doi.org/10.1007/s10484-007-9043-9

[20] Hashemian, P., Mashoogh, N. and Jarahi, L. (2015) Effectiveness of Music Therapy on Aggressive Behavior of Visually Impaired Adolescents. Journal of Behavioral and Brain Science, 5, 96-100. http://dx.doi.org/10.4236/jbbs.2015.53009 